\title{
ЦЕННОСТИ СОВРЕМЕННОЙ СТУДЕНЧЕСКОЙ МОЛОДЕЖИ
}

\author{
Светлана Гусакивская \\ Кременецкий областной гуманитарно-педагогический \\ институт им. Тараса Шевченко, Украина \\ Э-почта: s_husakivska@ukr.net
}

\begin{abstract}
Абстракт
В статье систематизируются результаты исследования ијенностей современной молодежи на примере студентов - будущих спещиалистов дошкольных образовательных учреждений Украинь и Республики Беларусь. Анализируются теоретические работы, в которых иченности описываются как важнейшие регуляторы поведения, личностного самоопределения и профессионального становления человека. Обосновывается, что особенно актуальным их ичеленаправленное формирование выступает относительно образования будущуи воспитателей детей дошкольного возраста, которые являются референтными трансляторами ценностей для новых поколений в наиболее сенситивный период для становления личности. Представлены результаты тестирования, в ходе которого были установлены ранговые соотношения цеенностей восточнославянских студентов. Ключевые слова: цүенности, студенческая молодежь, социиокультурный фактор.
\end{abstract}

\section{Введение}

Как отмечает И. Головинский, в XXI веке важное влияние на формирование личности имеют три фундаментальные составляющие: это глобальные изменения в мире, которые отображаются на всех странах в целом и каждом человеке в отдельности; новые этнопсихологические взгляды, что возникают вследствие различных новомодных веяний других культур; инновационные подходы в образовании и науке (Головинский, 2008).

Современные изменения социокультурной ситуации в мире вызывают переориентацию государственных требований к содержанию образования молодого поколения на европейские стандарты и рекомендации для обеспечения его качества, обусловливая процессы модернизации образования (Фиников, 2012). Мировые процессы в Украине отражены в программе «Освита» («Образование» - перевод наш), где акцентируется внимание на определении стратегии развития образования, создание системы для непрерывного обучения и воспитания, обеспечение возможностей постоянного духовного самосовершенствования личности, формирования интеллектуального и культурного потенциала как самой высокой ценности нации (Кабинет Министров Украины, 1993).

Научными исследованиями подтверждается тот факт, что среди всех других факторов влияния образования на становление общества именно ценности выступают тем субъективным опосредующим фактором, который способствует принятию и осмыслению каждой конкретной личностью актуальных общественных требований (Леонтьев, 2007). Ценности 
OF PSYCHOLOGY IN THE $21^{\text {st }}$ CENTURY Vol. 8, No. 1, 2014

проникают в индивидуальное сознание сначала как ценности внешние - общечеловеческие, общенациональные. Таким образом, осуществление человеком его жизненных выборов будет зависеть от их согласованности с общечеловеческими морально-этическими нормами, со способностью устанавливать и поддерживать необходимые контакты с другими людьми во всех сферах жизнедеятельности. В свою очередь, любые общечеловеческие ценности преломляются через региональную и национальную специфику своего осмысления и принятия (Знаков, Залевский, 2008). В частности, восточнославянское сообщество, пережив становление на протяжении долгого периода развития в истории соответствующего региона, занимает сегодня собственное место между культурами Востока и Запада и продолжает отстаивать свои интересы, взгляды, ценности и духовно-нравственные законы. Среди них ценности свободы, демократии, материальные, нравственные, общечеловеческие ценности (Боришевский, Пилипенко, Пенькова, 2013). Именно эти особенности представляют собой специфику социокультурной ситуации образования в Украине, России, Беларуси и других соседних странах.

На фоне общемировых процессов особо значимые задачи в современном высшем образовании - поиск оптимальных путей к самоопределению, самореализации, профессиональному становлению студенческой молодежи, следовательно, общее содействие полноценному развитию личности будущего специалиста. В связи со всем вышеизложенным, актуальной становится необходимость исследования разных аспектов процесса формирования ценностного самоопределения студенчества как ведущего фактора регуляции его жизнедеятельности, развития смысловых образований, необходимых для реального включения в общественную активность. Важное место такие исследования имеют, в частности, в профессиональной подготовке будущих специалистов дошкольных образовательных учреждений. Ведь именно им в недалеком будущем будет доверена особо ответственная общественная роль - воспитание и развитие детей, то есть привитие собственных ценностей словами и реальным поведением наиболее чувствительной в отношении влияния взрослых возрастной группе (Кидина, 2012; Кокун, 2013; Крижановская, 2011; Савелюк, 2012).

\section{Актуальность исследования}

Постоянные изменения социокультурной ситуации, нестабильность и кризисные явления в обществе приводят, соответственно, к периодическим трансформациям ценностей. Кроме того, к изменению индивидуальной их системы ведут закономерные возрастные факторы. Сенситивным периодом для развития и стабилизации многих качеств личности выступает особый для ее становления период жизни - студенческий возраст, который способствует формированию профессиональных, гражданских, мировоззренческих черт будущего специалиста, его способностей и творческого потенциала; интеллекта и качеств характера (Ананьев, 2001; Руснак, Иванчук, 2008).

Как отмечает А. Москаленко, период обучения в вузе оказывает существенное влияние на развитие ценностных ориентаций личности, а также на освоение новых социальных ролей - гражданских, семейных, нравственных, экономических, в процессе которого происходит закрепление ценностей, определение жизненных перспектив, в том числе, профессиональных (Москаленко, 2013). Н. Шевченко также убеждена в том, что указанная среда влияет на самоопределение студента, формирование его новых мировоззрений, принятия и усвоения им ценностей, построение жизненных целей, интересов, устремлений и принципов (Шевченко, 2005). Поэтому систематическое изучение сложного процесса формирования ценностей у молодежи - одна из актуальных задач современного высшего образования. Тем более, что в контексте современной общественной нестабильности эти ценности также очень динамичны и требуют регулярного, научно обоснованного мониторинга.

На разных этапах онтогенеза процесс развития ценностной сферы человека неравномерен и определяется влиянием объективных и субъективных факторов, в том числе, воздействием источников массовой информации, а также включенностью человека в ту или иную микрогруппу. А. Музыка отмечает в связи с этим, что человеку невозможно предоставить готовые ценности, а следует создать условия, чтобы субъект сформировал представление о 
том, как они приобретаются. Наличие же их индивидуальной системы позволяет каждому

присваивать себе уже принятые в культуре общества базовые ценности (Музыка, 2010). Однако, результаты многих эмпирических исследований показывают, что определенный ценностный выбор способно навязывать человеку общество. В частности, эту роль выполняют авторитет общественного мнения, события общегосударственного значения и даже реклама, которые значительно ограничивают свободу выбора (Знаков, Залевский, 2008).

Как видим, специфика предмета исследования требует учета социокультурного фактора формирования ценностной сферы личности. Социокультура, с точки зрения науки, является совокупностью социальных, культурных, политических интересов, а также ряда материальных и духовных структур, образцов поведения, которые объединены общей человеческой деятельностью. Она способствует усвоению общечеловеческих и профессиональных ценностей, обеспечивая гармонию субъекта в отношениях с окружающим миром. Центральным ядром социокультурной среды любой страны может считаться этнокультурная ситуация - совокупность и отражение материальных и духовных ценностей, хранимых определенным этносом на протяжении его развития на собственной территории, в частности, языка, традиций, религии. Ценности культуры отдельного народа формируют национальный менталитет, социальные роли граждан, их жизненные убеждения, формы поведения, общения, этические принципы духовной жизни. Итак, социокультура стимулирует развитие и усвоение общечеловеческих и профессиональных ценностей через их национальные проявления (Валиахметова, 2007).

\section{Цель исследования}

Как отмечает Н. Варич, наиболее перспективным путем формирования ценностей личности является обращение к общечеловеческим, традиционным идеалам, исходя из которых студент способен строить систему собственных взглядов и стремлений (Варич, 2010). Согласно ряду исследований, в традиционном украинском обществе преобладает матриархат семьи, а также покорность судьбе, эмоциональное и эстетическое восприятие мира, идеалы храбрости, демократизма, что играет важную роль в национальном воспитании. Таким образом, формирование индивидуальных ценностей должно предусматривать осознание общечеловеческих, национальных, религиозных ценностей молодежью, осмысление значимости собственной принадлежности к нации, идентификацию со своим народом, патриотизм (Король, 2012). В современной украинской культуре к высшим ценностям относятся: «Любовь», «Добро», «Правда», «Красота», «Гармония», «Совершенство», «Ответственность», «Честь», «Достоинство», «Совесть», «Свобода», «Самодостаточность», «Творчество» (Кисарчук, 2013).

Менталитет еще одного восточнославянского - белорусского - народа также формировался в течение многих поколений под влиянием различных этнических, социальных и исторических факторов. Неотъемлемыми его чертами являются миролюбие, толерантность, трудолюбие, выдержка, законопослушность, смелость, уважение к другим народам, добродушие. Исследования показывают, что белорусам присущи стремление добродетельно относиться к выполняемым делам, достигать поставленных целей, уважать национальные меньшинства, отстаивать справедливость (Чернявская, 1998).

Исторические события и общественно-политические процессы разделили государственными границами эти, как и многие другие, восточнославянские народы. К сожалению, закономерная этнокультурная самоидентификация и государственное самоопределение нередко ведут, вместе со всеми своими позитивными аспектами, к неправомерному обособлению каких-то «уникальных» особенностей родственных народов, что создает искусственные барьеры и даже конфликты на пути межнационального общения и сотрудничества. Следовательно, сравнительное изучение ценностей современной восточнославянской молодежи, что является основной целью данной статьи, позволит как сделать определенный вклад в исследование духовно-морального потенциала завтрашних специалистов сферы дошкольного образования, так и поспособствовать осознанию значительной общности мировосприятия и миропонимания двух братских славянских народов. 
OF PSYCHOLOGY IN THE $21^{\text {st }}$ CENTURY Vol. 8, No. 1, 2014

88

\section{Методология исследования}

\section{Общая характеристика исследования}

Ценности - один из основных элементов субъектной культуры, которые определяют характер отношений между представителями конкретной культуры, постепенно превращаясь в определенную ее черту. Исследования ценностей осуществляются на двух уровнях - индивидуальном (установки, которыми руководствуется человек в своей жизнедеятельности) и культурном (общественные представления). Если ценности на индивидуальном уровне в психологии изучаются достаточно широко, то на культурном они менее исследованы. Такие современные исследования ценностей основываются на идеях В. Билски, Г. Хофстеде, Ш. Шварца, согласно которым измерения культурных ценностей отражают альтернативные решения определенными группами людей основных проблем жизнедеятельности. Кросскультурные исследования, проведенные во многих странах на основе теории Ш. Шварца, показывают ее перспективность для изучения ценностей с целью выявления социокультурной их специфики (Кисарчук, 2013).

Для исследования системы ценностей студенческой молодежи использовалась методика «Опросник ценностей» Ш. Шварца, направленная на изучение универсальных общечеловеческих ценностей, существующих в различных формах во всех культурах (Schwartz, 1992; Карандашев, 2004). С помощью данного опросника выявлялись следующие типы ценностей: 1) Власть (Power) - центральная цель этого типа заключается в достижении социального статуса или престижа, контроля или доминирования над людьми и средствами (авторитет, богатство, социальная власть, сохранение своего имиджа, общественное признание). Ценности власти подчеркивают достижение доминантной позиции в рамках целой социальной системы. 2) Достижение (Achievement) - определяющая цель этого типа ценностей - личный успех через проявление компетентности в соответствии с социальными стандартами. Проявление социальной компетентности (что составляет содержание этой ценности) в условиях доминирующих культурных стандартов влечет за собой социальное одобрение. Ценности достижения (успешный, амбициозный) подчеркивают активное проявление компетентности в непосредственном взаимодействии. 3) Гедонизм (Hedonism) - мотивационная цель данного типа определяется как наслаждение или чувственное удовольствие (удовольствия, наслаждение жизнью). 4) Стимуляция (Stimulation) - цель этого типа ценностей заключается в стремлении к новизне и глубоким переживаниям; потребности в стимуляции приводят к индивидуальным различиям в значимости этой ценности. 5) Самостоятельность (SelfDirection) - определяющая цель этого типа состоит в самостоятельности мышления и выбора способов действия в творчестве и исследовательской активности. Самостоятельность как ценность производна от потребности в самоконтроле, самоуправлении, автономности и независимости. 6) Универсализм (Universalism) - цель данного типа ценностей - понимание, терпимость и защита благополучия всех людей и природы. 7) Доброта (Benevolence) - это более узкий «просоциальный» тип ценностей по сравнению с универсализмом. Лежащая в ее основе доброжелательность сфокусирована на благополучии в повседневном взаимодействии с близкими людьми (полезность, лояльность, снисходительность, честность, ответственность, дружба, зрелая любовь). 8) Традиции (Tradition) - цель данной ценности - уважение, принятие обычаев и идей, которые существуют в культуре (уважение традиций, смирение, благочестие, принятие своей участи), и следование им. 9) Конформность (Conformity) - определяющая цель этого типа - сдерживание и предотвращение действий, а также склонностей и побуждений к действиям, которые могут причинить вред другим. Данная ценность является производной от требования сдерживать склонности, имеющие негативные социальные последствия. 10) Безопасность (Security) - безопасность для других людей и себя, гармония, стабильность общества и взаимоотношений, в частности, социальный порядок, безопасность семьи, национальная безопасность, взаимопомощь, чувство принадлежности (Карандашев, 2004). Согласно теории Ш. Шварца, ценности личности существуют на двух уровнях: на уровне нормативных идеалов и на уровне индивидуальных 
приоритетов. Первый уровень более стабилен и отражает представления человека о том, как нужно поступать, определяя тем самым его жизненные принципы поведения. Второй уровень более зависим от внешней среды, например, от группового давления и соотносится с конкретными поступками человека (Schwartz, 1997). Этот аспект теории ценностей учитывался в процедуре проведения опроса.

\section{Выгорка}

Исследование было проведено в декабре 2013 года на выборке студентов двух стран - Украины и Республики Беларусь, в состав которой вошел 261 человек. Объем выборки обоснован численностью академических групп студентов. Первую подвыборку составили 134 студента Кременецкого областного гуманитарно-педагогического института им. Тараса Шевченко (Украина), вторую - 127 человек Брестского государственного университета им. А. С. Пушкина (Республика Беларусь), обучающихся по специальности «Дошкольное образование».

\section{Инструмент исследования}

Опросник состоит из двух частей, отличающихся процедурой проведения. Первая его часть («Обзор ценностей») предоставляет возможность изучить нормативные идеалы, ценности личности на уровне убеждений, а также их структуру, оказывающую наибольшее влияние на всю личность, но не всегда проявляющуюся в реальном социальном поведении. Вторая часть опросника («Профиль личности») изучает ценности на уровне поведения, то есть индивидуальные приоритеты, наиболее часто проявляющиеся в поведении личности. Различие показателей по типам ценностей в этих двух частях опросника, характеризующих два уровня функционирования ценностей, отражает ценностное давление, которое осуществляется, с одной стороны, через социализацию и, с другой стороны, посредством референтной группы и традиций. Первая часть («Обзор ценностей») представляет собой два списка слов, характеризующих в сумме 57 ценностей. Все они имеют ясную мотивационную цель и являются в той или иной мере значимыми для разных культур. В первом списке содержатся терминальные ценности, выраженные в виде существительных. Во втором списке содержатся инструментальные ценности, выраженные в виде прилагательных. Испытуемым предлагалось оценить степень важности каждой ценности как руководящего принципа их жизни с помощью шкалы от -1 до 7. Чем выше балл в диапазоне - 1,0, 1, 2, 3, 4, 5, 6, 7, тем более важной представляется эта ценность.

Во второй части опросника («Профиль личности») приводится список из 40 описаний человека, соответствующих тому или иному из 10 типов ценностей. Испытуемый должен был оценить, в какой степени описанный в опроснике человек похож или не похож на него с помощью шкалы из 5 позиций: от «очень похож на меня» до «совсем не похож на меня». Для работы над опросником необходимо 30-50 минут. В ходе исследования мы обращали внимание испытуемых на то, что все пункты опросника должны быть заполнены. Если в ходе работы у них возникали вопросы, - отвечали на них, но при этом не советовали, какой выбрать ответ.

Обработка данных проводилась путем соотнесения ответов каждого респондента с ключом (Карандашев, 2004). В нем указаны номера пунктов обеих частей опросника, соответствующие каждому типу ценностей, после этого вычислялся средний балл по данной ценности, чтобы показать степень ее значимости. При обработке первого раздела опросника - «Обзор ценностей» (уровень нормативных идеалов) - результаты по спискам 1 и 2 суммировались. Перед подсчетом результатов второго раздела опросника - «Профиль личности» - шкала опросника переводилась в баллы.

При первичной обработке данных по каждой части опросника («Обзор ценностей» и «Профиль личности») высчитывался средний балл для выбранных испытуемым ответов в соответствии с ключом. Обработка проводилась отдельно для каждого из 10 типов ценностей. Величина этого среднего балла по отношению к другим позволила судить о степени 
OF PSYCHOLOGY IN THE $21^{\text {st }}$ CENTURY Vol. 8, No. 1, 2014

значимости этого типа ценностей для испытуемого. В соответствии со средним баллом по каждому типу ценностей устанавливалось их ранговое соотношение. Каждой ценности присваивался ранг от 1 до 10. Первый - типу ценностей, имеющему наиболее высокий средний балл, десятый - имеющему самый низкий средний балл (ранг от 1 до 3 , полученный соответствующими типами ценностей, характеризует их высокую значимость для испытуемого. Ранг от 7 до 10 свидетельствует о низкой значимости соответствующих ценностей). Анализ величины рангов, которые занимают определенные ценности относительно других, позволил сделать вывод об их относительной значимости для исследованной выборки.

\section{Результаты исследования}

В результате опроса, целью которого было определение ценностей украинской и белорусской студенческой молодежи по методике Ш. Шварца «Опросник ценностей», были получены следующие средние значения и соответствующие ранговые показатели всех типов ценностей, которые отражены в таблицах 1,2 .

\section{Таблица 1. Средние показатели значимости ценностей на уровне} нормативных идеалов.

\begin{tabular}{ccccc}
\hline Типы ценностей & $\begin{array}{c}\text { коГПИ им. } \\
\text { Т.Шевченко }\end{array}$ & $\begin{array}{c}\text { Ранговые } \\
\text { значения }\end{array}$ & $\begin{array}{c}\text { БГУ им. } \\
\text { А.Пушкина }\end{array}$ & $\begin{array}{c}\text { Ранговые } \\
\text { значения }\end{array}$ \\
\hline Конформность & 4,15 & 4 & 4,95 & 1 \\
Традиции & 4,46 & 3 & 4,4 & 2 \\
Доброта & 4,75 & 1 & 4,05 & 3 \\
Универсализм & 3,8 & 6 & 3,6 & 5 \\
Самостоятельность & 3,9 & 5 & 3,3 & 7 \\
Стимуляция & 2,55 & 10 & 2,9 & 10 \\
Гедонизм & 2,95 & 9 & 2,95 & 9 \\
Достижения & 3,45 & 7 & 3,15 & 8 \\
Власть & 3,15 & 8 & 3,55 & 6 \\
Безопасность & 4,55 & 2 & 3,8 & 4 \\
\hline
\end{tabular}

Как видно из таблицы 1, на уровне нормативных идеалов (индивидуальных и групповых убеждений) для всей выборки в целом важнейшими являются типы таких ценностей, как «доброта» (забота о благополучии близких) и «традиции» (уважение и ответственность за культурные достижения своего народа). Однако, несколько отличной для украинских и белорусских студентов является значимость ценностей безопасности (безопасность для других людей и себя, гармония, стабильность общества и взаимоотношений) и конформности (избегание поступков, которые могут навредить другим) соответственно.

Таблица 2. Средние показатели значимости ценностей на уровне индивидуальных приоритетов.

\begin{tabular}{ccccc}
\hline Типы ценностей & $\begin{array}{c}\text { КОГПИ им. } \\
\text { Т.Шевченко }\end{array}$ & $\begin{array}{c}\text { Ранговые } \\
\text { значения }\end{array}$ & $\begin{array}{c}\text { БГУ им. } \\
\text { А.Пушкина }\end{array}$ & $\begin{array}{c}\text { Ранговые } \\
\text { значения }\end{array}$ \\
\hline Конформность & 2,5 & 5 & 2,75 & 1 \\
Традиции & 2,3 & 7 & 2,85 & 2 \\
Доброта & 3,3 & 2 & 2,62 & 5 \\
Универсализм & 2,45 & 6 & 2,67 & 3 \\
Самостоятельность & 3,33 & 1 & 2,65 & 4
\end{tabular}




\begin{tabular}{ccccc}
\hline Типы ценностей & $\begin{array}{c}\text { КОГПи им. } \\
\text { Т.Шевченко }\end{array}$ & $\begin{array}{c}\text { Ранговые } \\
\text { значения }\end{array}$ & $\begin{array}{c}\text { БГУ им. } \\
\text { А.Пушкина }\end{array}$ & $\begin{array}{c}\text { Ранговые } \\
\text { значения }\end{array}$ \\
\hline Стимуляция & 1,6 & 10 & 2,25 & 6 \\
Гедонизм & 2,05 & 8 & 1,5 & 10 \\
Достижения & 2,95 & 3 & 1,7 & 9 \\
Власть & 2,0 & 9 & 2,0 & 8 \\
Безопасность & 2,65 & 4 & 2,15 & 7 \\
\hline
\end{tabular}

Из таблицы 2 видно, что на уровне индивидуальных приоритетов (конкретных поступков) у украинских студентов в наибольшей степени проявляются ценности - «самостоятельность», «доброта» и «достижения», тогда как для белорусских опрашиваемых приоритетными являются «конформность», «традиции» и «универсализм». На последних позициях исследуемых находятся ценности «стимуляция», «гедонизм» и «власть».

Для определения уровня статистической значимости различий средних величин в двух независимых выборках применялся статистический критерий Стьюдента. По известной формуле определено значение его t-критерия (Годфруа, 1997). Наблюдаемые значения критерия $\mathrm{t}_{c n}$ (при степени свободы $\mathrm{t}_{c n}=1,96$ и для уровня достоверности $\mathrm{p}=0,05$ ) представлены в таблице 3.

Таблица 3. Значение критерия $t_{c n}$ ценностей.

\begin{tabular}{ccc}
\hline Типы ценностей & $\begin{array}{c}\text { Уровень нормативных } \\
\text { идеалов (tсп) }\end{array}$ & $\begin{array}{c}\text { Уровень } \\
\text { индивидуальных } \\
\text { приоритетов (tсп) }\end{array}$ \\
\hline Конформность & 1,90 & 0,59 \\
Традиции & 0,14 & 1,3 \\
Доброта & 1,67 & 1,61 \\
Универсализм & 0,48 & 0,52 \\
Самостоятельность & 1,43 & 1,61 \\
Стимуляция & 0,83 & 1,55 \\
Гедонизм & 0 & 1,31 \\
Достижения & 1,71 & 1,90 \\
Власть & 0,95 & 0 \\
Безопасность & 1,79 & 1,19 \\
\hline
\end{tabular}

Поскольку $t_{c n}<t_{\kappa p}$ для каждого типа ценностей, соответственно данным таблицы 3 , статистически значимые различия между средними показателями двух выборок не установлены.

\section{Анализ данных}

Проведенное исследование позволяет отметить, что среди полученных результатов опроса не установлены статистически значимые различия в уровнях значимости вышеперечисленных типов ценностей студентов Украины и Республики Беларусь. Однако, наблюдаются некоторые их различия на уровне нормативных идеалов (убеждений) и на уровне индивидуальных приоритетов (конкретных поступков). Так, на первом месте для всей выборки в целом важнейшими являются ценности «доброта» (цель этой ценности - сохранение благополучия людей, с которыми индивид находится в личных контактах: полезность, лояльность, снисходительность, честность, ответственность, дружба, зрелая любовь) и «традиции» (уважение, принятие обычаев и идей, которые существуют в культуре: 
OF PSYCHOLOGY

IN THE $21^{\text {st }}$ CENTURY Vol. 8, No. 1, 2014

92

уважение традиций, смирение, благочестие, принятие своей участи, умеренность и следование им). Однако, несколько отличной для украинских и белорусских студентов является значимость их представлений о ценностях безопасности (безопасность для других людей и себя, гармония, стабильность общества и взаимоотношений) и конформности (избегание поступков, которые могут навредить другим) соответственно.

На уровне индивидуальных приоритетов у украинских студентов в наибольшей степени проявились ценности самостоятельности (самостоятельность в мышлении и выборе способов действия, в творчестве и исследовательской активности), доброты и достижений (личный успех через проявление компетентности в соответствии с социальными стандартами. Ценности достижения (например, успешный, амбициозный) подчеркивают активное проявление компетентности в непосредственном взаимодействии, тогда как для белорусских опрашиваемых приоритетными являются «конформность» (сдерживание и предотвращение действий, а также склонностей и побуждений к действиям, которые могут причинить вред другим или не соответствуют социальным ожиданиям), «традиции» и «универсализм» (понимание, терпимость и защита благополучия всех людей и природы). На последних позициях исследуемых находятся ценности «стимуляция», «гедонизм» и «власть».

Следовательно, в убеждениях студентов преобладают представления о том, что надо стремиться к сохранению благополучия окружающих людей, быть полезным, обладать моральными качествами; уважать обычаи и идеи, которые существуют в их культуре и следовать им. Важно отметить, что в реальном поведении для студентов важно быть самостоятельными, достигать личных успехов, а также иметь уважение к родителям и старшим, стремиться к благополучию людей и природы.

\section{Дискуссия}

Отечественная наука имеет целый ряд работ, посвященных изучению ценностносмысловой сферы будущих учителей, социальных педагогов, психологов, социологов, экономистов, юристов, а также воспитателей (Антонова, 2011; Вилюжанина, 2006; Коберник, 2010; Крижановская, 2011; Максимчук, 2000). Но на сегодня не было осуществлено целостных психологических исследований ценностей будущих специалистов дошкольных образовательных учреждений.

В данном опросе украинские и белорусские студенты, будущие специалисты дошкольных образовательных учреждений, выделяют значимые для них типы ценностей, выражающих их заботу о благополучии близких людей, уважение к своему народу, стремление к гармонии и стабильности в обществе и взаимоотношениях людей.

Современное общество, рассматривающее образование как пространство культурного и политического диалога, актуализирует проблему формирования у студентов направленности на гуманистические ценности. В то же время, как показывают исследования, приоритет эгоистически-престижных ценностей над нравственно-духовными вызывает обеспокоенность современной педагогической общественности (Позднякова, 2011).

Несмотря на этот факт, Н. Антонова среди наиболее значимых ценностей в студенческий период выделяет «счастье родных», «физическое здоровье», «любовь», «счастливую семью», «душевную гармонию», а менее важными являются ценности «свобода», «эстетика», «социальный статус» и «отдых» (Антонова, 2011). Очевидные различия между результатами данных исследований можно объяснить, прежде всего, спецификой использованных методов и методик, а также, вероятно, спецификой выборок молодежи.

Отличные группы ценностей также описывает Л. Коберник: 1) ценности личной жизни (здоровье, любовь, хорошие и верные друзья, счастливая семейная жизнь); 2) индивидуальные ценности (материальное обеспечение, самостоятельность, красота, высокие притязания, смелость, твердая воля, нетерпимость к недостаткам, жизнерадостность); 3) этические ценности (воспитанность, чуткость, честность, милосердие); 4) ценности профессиональной направленности (интересная работа, общественное признание, уверенность в себе, образованность, рационализм); 5) ценности развития и познания (развитие, творчество, активная деятельная жизнь) (Коберник, 2010). 
У будущих педагогов как широкого круга специалистов Н. Максимчук констатирует наличие общечеловеческих, профессиональных, материальных, статусных ценностных ориентаций и ориентаций на самосовершенствование. Среди профессиональных ценностей студентов, по данным исследовательницы, оказались недостаточно значимыми жизненно важные ценности - любовь к детям, профессия как призвание, уважение детей, преданность работе, терпеливость и понимание воспитанников (Максимчук, 2000).

Разделяем мнение Н. Зотовой о том, что личность воспитателя, по сравнению с представителями других педагогических профессий, находится в особой ситуации: он является мощным фактором формирования личности ребенка. В реальной деятельности педагог открыто демонстрирует усвоенные им ценности и модели поведения. Воспитателя можно назвать личностью, которая своим существованием, в частности, поступками, жизненными нормами и правилами, меняет другого (Зотова, 2007).

Необходимо отметить, что Т. Пониманская среди приоритетных ценностей в структуре ценностных ориентаций воспитателя видит, в первую очередь, ценности самопринятия и принятия личности ребенка, которые взаимообусловлены и способствуют формированию у него высоких гуманистических ценностей. Их реализация, по мнению ученой, требует наличия соответствующих личностных качеств, необходимых в профессиональной работе педагога дошкольного образовательного учреждения: способность к рефлексии и контроля результатов педагогической деятельности, гуманистического взаимодействия с ребенком, развития его личности, возможность эмоциональной и моральной поддержки, стремление к близости, обеспечение психологического комфорта, постоянная направленность на самообучение и самовоспитание для совершенствования своего мастерства, выявления и учета в процессе воспитания детей их потребностей и интересов (Пониманская, 2004).

Е. Арасланова считает, что в профессиональной деятельности воспитателей особую значимость имеют установки на взаимодействие с детьми, которые являются разновидностями фиксированных социальных установок. Содержательными компонентами этих установок являются: самооценка общения с детьми, личностные характеристики педагога, направленность его профессионально-личностного развития, профессиональные ценности (Арасланова, 2008).

По мнению ряда ученых, в профессиональной подготовке будущих воспитателей необходимо учитывать мотивы и факторы профессионального выбора; личное отношение к социальной значимости профессии и профессиональным ценностям; желание работать по профессии; развитие личностных качеств и интереса к педагогической деятельности; социально и профессионально значимых мотивов; формирования психологической готовности у будущих воспитателей (Антонова, 2011; Качалина, 2009; Климина, 2013; Кудашкина, 2010). Итак, важно обобщить, что упомянутые составные части (ценности, личностные качества, мотивы и факторы профессионального выбора, особенности учебно-профессиональной деятельности) взаимообусловлены и целостно влияют на формирование личности будущего воспитателя дошкольного образовательного учреждения. Перспектива дальнейших исследований рассматривается как реализация формирующего эксперимента с целью выявления психологических особенностей становления ценностей личности будущего воспитателя детей дошкольного возраста.

\section{Выводы}

В результате обобщения результатов проведенного исследования для всей выборки в целом можно утверждать, что на уровне личностных представлений студентов - будущих воспитателей детей дошкольного возраста - приоритетными выступают ценности доброты и поддержки традиций. На уровне регуляции поведения у современных украинских респондентов в наибольшей степени проявляются самостоятельность, доброжелательность, благополучие в повседневном взаимодействии с близкими людьми, достижения; у белорусских - конформность, сохранение традиций и защита благополучия окружающего мира.

Статистически значимых различий между соответствующими выборками не обнаружено, что демонстрирует сходство традиций, общественных норм жизнедеятельности, 
OF PSYCHOLOGY

IN THE $21^{\text {st }}$ CENTURY

Vol. 8, No. 1, 2014

94

территориальную близость и духовное родство Украины и Беларуси как двух соседних восточнославянских стран. При этом, демонстрируя некоторую свою межнациональную универсальность, ценности являются многоуровневой иерархической системой, включающей общечеловеческие, профессиональные и личностные ориентиры жизнедеятельности. Таким образом, выявленные доминантные ценности будущих воспитателей дошкольных образовательных учреждений Украины и Беларуси в целом отражают общие духовные ориентиры восточнославянских народов и соответствуют общественным задачам этой в высшей степени гуманной профессии.

\section{Литература}

Ананьев, Б. Г. (2001) О проблемах современного человекознания. Санкт-Петербург: Питер.

Антонова, Н. О. (2011) Ціннісні орієнтації студентів з різним типом готовності до професійної діяльності. Практична психологія та сочіальна робота. 3, 13-23.

Арасланова, Е. В. (2008) Психологическое содержание установок воспитателей дошкольных образовательных учреждений на взаимодействие с детьми. Нижний Новгород: НГУ.

Байдаров, Е. У. (2010). Информационно-образовательные и воспитательные стратегии в современном обществе. Минск: Право и економика.

Боришевський, М. Й., Пилипенко, Л. І., Пенькова, О. І. (2013). Виховання духовності особистості. Кіровоград: Імекс-ЛТД.

Валиахметова, Т. А. (2007). Социокультурные цеенности этноса как фактор формирования нравственных отношений учащчихся школ искусств. Екатеринбург: ГОУ ВПО «Челябинская государственная академия культуры и искусств»

Вілюжаніна, Т. А. (2006) Динаміка иіннісно-смислової сфери особистості в процесі професійного становлення майбутніх психологів. Київ: Інститут психології ім. Г. С. Костюка

Годфруа, Ж. (1997). Что такое психология. Москва: Мир.

Головінський, І. 3. (2008). Пращฺі з психологї. Київ: Аконіт.

Знаков, В. В., Залевский, Г. В. (2008). Ценностнье основания психологической науки и психология цченностей. Москва: «Институт психологии РАН».

Зотова, Н. (2007). О ценностных смыслах профессии педагога. Дошкольное воспитание, 2, 100-104.

Кабінет міністрів України (1993). Державна національна програма «Освіта» («Україна XXI століття»).

Карандашев, В. Н. (2004). Методика Шварича для изучения иченностей личности: концепщия и методическое руководство. Санкт-Петербург: Речь.

Качалина, Е. Б. (2009). Становление и развитие профессиональной позиции студентов педагогического колледжа. Москва: МГУ.

Кідіна, Л. М. (2012). Формування професійної компетентності майбутніх вихователів дошкільних навчальних закладів у процесі педагогічної практики. Слов'янськ: СДПУ.

Кісарчук, 3. Г. (2013). Методичні рекомендації щзодо врахування соціокультурних чинників в теорії та практиці психотерапевтичної допомоги особистості. Кіровоград: Імекс-ЛТД.

Климина, Л. В. (2013). Региональная система повышения квалификаичи педагогов дошкольного образования. Самара: СГУ.

Коберник, Л. О. (2010). Ціннісні орієнтації як чинник виникнення та подолання конфліктних форм поведінки в юнацькому віщฺі. Київ: Інститут психології ім. Г. С. Костюка.

Кокун, О. М. (2013). Психофізіологічне забезпечення становлення фахівия у професіях типу „людиналюдина”. Кіровоград: Імекс-ЛТД.

Король, Л. Д. (2012). Психологія формування національного характеру. Острог: Видавництво Національного університету „Острозька академія”. 
Крижановська, 3. С. (2011). Мотиваційні чинники професійної самореалізайї фахівців дошкільних закладів. Луцьк: ВНУ ім. Лесі Українки.

Кудашкина, О. В. (2010). Развитие ценностных ориентаций педагога дошкольного образования на этапе вузовского обучения. Саранск: МГУ им. Н. П. Огарева

Леонтьев, Д. А. (2007). Психология смысла. Москва: Смысл.

Максимчук, Н. П. (2000). Психологічні особливості становлення ціннісних орієнтацій майбутнього вчителя у прочесі професійної підготовки. Київ: Інститут психології ім. Г. С. Костюка.

Маслоу, А. Г. (1997). Дальние предель человеческой психики. Санкт-Петербург: Евразия.

Москаленко, О. В. (2013). Структурні компоненти ціннісно-смислової сфери особистості. Київ: Вісник НТУУ „КПІ”. Філософія. Психологія. Педагогіка, 1.

Музика, О. Л. (2010). Ціннісна регуляція і ціннісна підтримка розвитку творчих здібностей (теоретична модель і принципи побудови методики). Практична психологія та соиіальна робота, 6, 1-7.

Позднякова, А. Л. (2011). Формирование иенностного отномения будущего спещииалиста к профессиональной деятельности. Чита: ЗГГПУ им. Г. Н. Чернышевского

Поніманська, Т. І. (2004). Підготовка педагогічних кадрів для системи доикільної освіти. Київ: Академвидав.

Руснак, І. С., Іванчук, М. Г. (2008). Педагогіка і психологія вищої школи. Чернівці: Рута.

Савелюк, Н. М. (2012). Психологія педагогічна. Кременець: КОГПІ ім. Тараса Шевченка.

Фініков, Т. В. (2012). Входження національної системи вищої освіти в європейський простір вищої освіти та наукового дослідження. Київ: Таксон.

Чернявская, Ю. В. (1998). Народная культура и национальные традиции. Минск: Харвест.

Шевченко, Н. Ф. (2005). Становлення професійної свідомості практичних психологів у процесі фахової підготовки. Київ: Міленіум.

Schwartz, S.H. (1992). Universals in the structure and content of values: Theoretical advances and empirical tests in 20 countries. Orlando, FL: Academic.

Schwartz, S.H., Bilsky, W. (1994). Values and personality. European Journal of Personality, 8, 163-181.

Schwartz, S.H., Sagiv, L. (2000). Value priorities and subjective well-being: directrelations and congruity effects. European Journal of Social Psychology, 2, 177-185.

\section{Summary}

\section{MODERN STUDENTS' VALUES}

\section{Svetlana Husakivska \\ Kremenets Regional Humanitarian-Pedagogical Institute named after Taras Shevchenko, Ukraine}

The research results of modern youth's values, considering Ukrainian and Belarusian students, as future specialists in pre-school institutions of the countries mentioned, are revealed in the article. These values prove to be important regulators of students'behavior, self-determination, personal and professional development. Purposeful becoming of preschool age children's educators seems to be especially up-to date. Students turn to be the role models of norms, rules and ideals for new generations. Well-known Schwartz's "Value Inventory" technique is used to determine modern students'values. Firstly, it gives the opportunity to identify values at the level of assurance and the actual behaviour of a personality. The experiment reveals that the values of kindness and following the traditions are of primary importance for all the respondents. Secondly, Ukrainian students seem to appreciate the values of independence, kindness and 
OF PSYCHOLOGY IN THE $21^{\text {st }}$ CENTURY

Vol. 8, No. 1, 2014

96

achievements; Belarusian - agreeableness, tradition and universalism. However, statistically significant differences between the samples are not confirmed. This, indeed, reveals the impact of the respondents' nature in following similar East Slavic nations'socio-cultural traditions, principles and norms, territorial proximity of Ukraine and Belarus, their spiritual kinship.

Key words: socio-cultural factor, modern students and their values.

Advised by Irena Gailiene, SMC "Scientia Educologica", Lithuania

Received: February 12, 2014

Accepted: March 28, 2014 